\title{
Yield and Morphological İnvestıgation of Different Tigger Melon (Cucumis Melo Dudaim) Genotypes Belonging to Sirnak/Turkey Region
}

\author{
Yelderem Akhoundnejad* Nevzat Sevgin \\ Sirnak University, Agricultural Faculty, Department of Horticulture, Idil-Sirnak-Turkey
}

\begin{abstract}
This study was performed in 18 different tigger melon (CUCUMIS MELO DUDAIM) genotypes which were collected from the various villages of İdil/Sirnak. In the study, measurements of brix in fruit, SPAD, dry matter in fruit, total yield, seed weight, seed weight per fruit, seed length, number of seeds per fruit, fruit weight, fruit length, fruit width, fruit wall thickness, main stem diameter, main stem length, the main number of nodes in the stem, nod in the main stem were carried out. In addition, the experiment was performed with 4 replications including 10 plants per every replicate. The experiment was made according to the random design of the trial blocks. The data obtained at the end of the experiment statistical analyzes were made by evaluating with JMP8 program and the means were compared according to LSD test. In addition, cluster analysis was also performed in terms of similarity between genotypes in the experiment. As a result, when the fruit measurements are examined; total fruit yield was recorded with high amount in the tigger melon genotype, on the other hand, genotype number 13 of the tigger melon was recorded as the low. According to the obtained results, morphological and pomological measurements demonstrated difference from each other in 18 tigger melon melon plants and fruits.

Keywords: Tigger melon, Seed, CUCUMIS MELO DUDAIM, SPAD, Brix.
\end{abstract}

DOI: $10.7176 / \mathrm{JBAH} / 9-10-09$

Publication date:May $31^{\text {st }} 2019$

\section{Introduction}

Latin name of this plant which is from Cucurbitaceae Family is Cucumis melo dudaim and it is also called tigger melon. It is an annual plant, can climb with the help of branches. The plant is sometimes grown in tropical regions rather than warm temperate zones. The small size of this fruit is seen in the market as a melon that can be purchased for individual consumption and as ornament (Lorenz1, at al., 2006). These melons also provide an edible oil and have a variety of traditional medical applications. These melons can be grown in tropical zones from a warm temperate zone to a height of 1000 meters. They grow best in regions where the annual daytime temperatures range from 18 to $30{ }^{\circ} \mathrm{C}$. They can tolerate $9-35{ }^{\circ} \mathrm{C}$ and prefer an average annual rainfall of 1.000 $1.300 \mathrm{~mm}$, however, they tolerate rainfall of $900-2,500 \mathrm{~mm}$ and prefer a $\mathrm{pH}$ in the range of $6-7.5$, with a tolerance of 5 to 8.7 (418). They grow best in areas where there is not much rainfall or humidity, because these conditions reduce fertilization and lead to diseases of the leaves. It takes 3-4 months to produce the crop from the seed which was killed by frost (Tindall, 1983). Fruit weights are usually less than 200 grams, but in some genotypes fruit weights are seen in excess. Fruit flesh is a white and slightly sweet flavor, but a nice aroma and fragrance has been determined as high quantity (Lorenzı at al, 2006). Seed - crude (Tanaka, T., and Nakao, S. 1976). Hazelnut oil is a rich oil, but it is very small because the seed is small and covered with a fibrous sheet. The seed contains 12.5\% - 39.1\% fat (Duke, J. A., and Ayensu, E. S. 1985). An edible oil is obtained from the seed $(105,183)$. Melon (Cucumis melo L.) is an important vegetable both in Turkey and in Worldwide and has 24 million and 1.61 million tons production respectively with an area of 1,07 million and 95 thousand hectares (Anonymous, 2010). In addition, Turkey located in secondary genetic diversity center, from Asia to Japan (Pitrat M., et al, 1999; Jeffrey 2001; Sensoy S., et al, 2007). 15 melon genotypes collected by Şensoy et al, (2008) were cultivated in 100th year University Horticulture Application Land and their phenotypic characterizations were examined. They have done some phenological and morphological measurements in melon genotypes and examined their properties. In the investigation in 31 different melon genotypes performed by Soltani et al, (2010), differences were seen in terms of morphological characterization in some melon genotypes. According to the results obtained from the studies, differences and similarities between genotypes were shown by cluster analysis (Karaagac and Baklaya 2009).

\section{Materials and Methods}

The research was conducted in 2018 in the experiment area of the Department of Horticulture, Faculty of Agriculture, Sirnak University. 18 different Tigger melon genotypes were used in the experiment (Figure 1). The materials were collected from different villages of İdil region and from different locations (Table 1). The experiment was carried out with 4 repetations and 10 plants totally, seeds were planted at each repetation. The experiment was conducted according to the randomized block pattern and the data obtained at the end of the 
experiment were subjected to JMP program and statistical analyzes were made and the means were compared according to LSD test. The experiment was conducted according to the randomized block pattern by subjecting to JMP package program. Besides the average data were compared to LSD test. In addition, cluster analysis was conducted in our study. Tigger melon seed was planted directly in the soil. Besides, seeds were planted without giving water. In experiment, seeds were planted as $60 \mathrm{~cm}$ intervals on line and $120 \mathrm{~cm}$ intervals between lines. The seed planting was performed on date of May 15, 2018 and the harvested on dates of 2, 7, 12 August 2018 and the yield of each harvest was recorded. After planting, on June 28, 2018, chlorophyll content (SPAD), number of main trunk knuckles, trunk length, main trunk diameter, main arm length were measured with digital caliper and meter. On each repetation, average fruit weight $(\mathrm{g})$, average fruit length $(\mathrm{cm})$, average fruit diameter $(\mathrm{cm})$, average fruit thickness $(\mathrm{mm})$, amount of water soluble dry matter (WSDM \%), the number of seeds per fruit (pieces / fruit), seed weight per fruit (g / fruit), seed diameter $(\mathrm{mm})$, seed length $(\mathrm{mm})$ measurements were made.

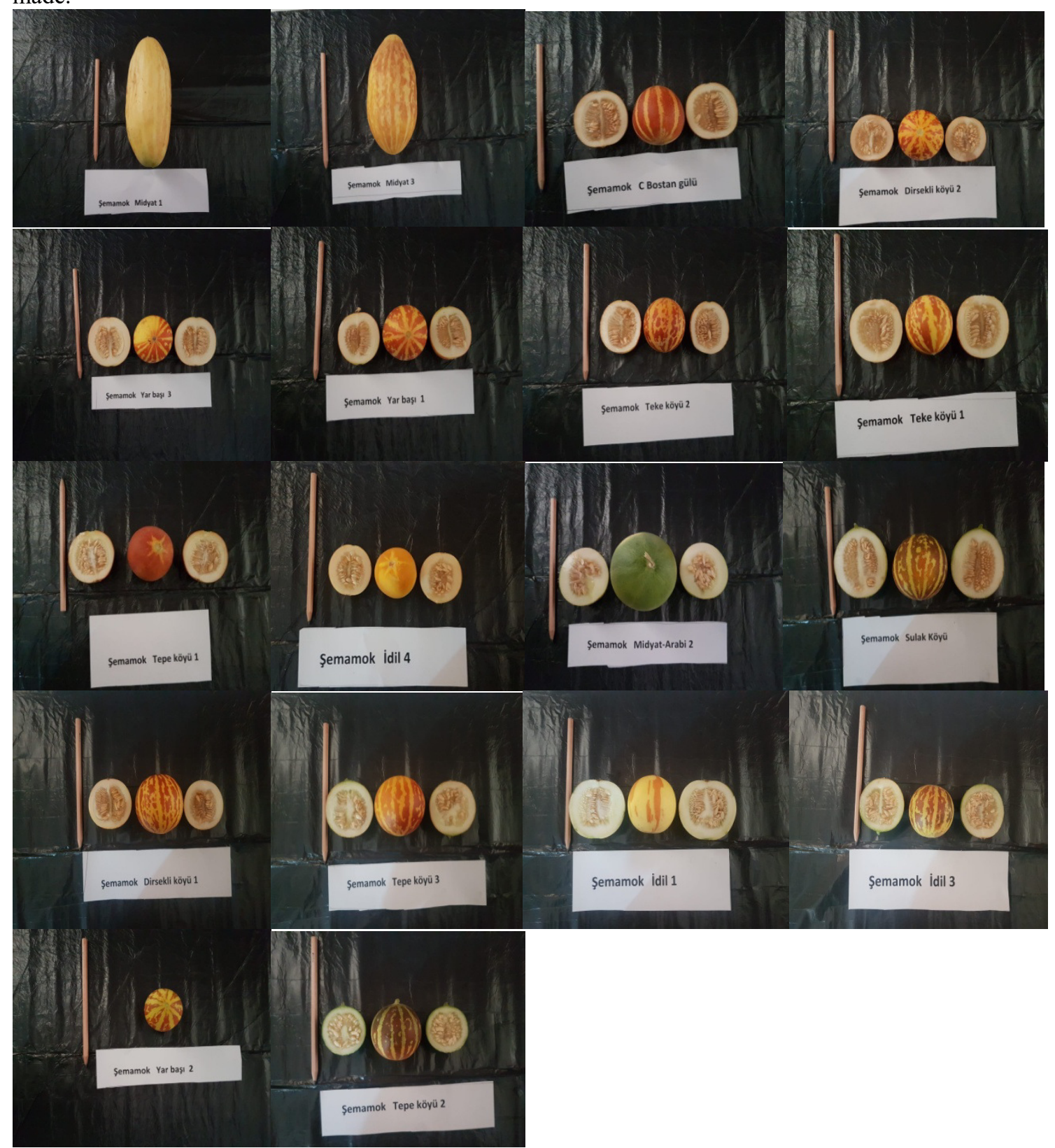

Figure 1. An image of 18 different Tigger melon genotypes. 
Table 1. Tigger melon (CUCUMIS MELO DUDAIM)) genotypes used in the experiment.

\begin{tabular}{cc}
\hline Genotype & Origin \\
\hline şemamok1 & İdil 1 \\
şemamok3 & İdil3 \\
şemamok4 & İdil1 \\
şemamok5 & Tepe köyü1 \\
şemamok6 & Tepe köyü2 \\
şemamok7 & Tepe köyü3 \\
şemamok8 & Teke köyü1 \\
şemamok9 & Teke köyü2 \\
şemamok10 & Yar baş11 \\
şemamok11 & Yar baş12 \\
şemamok12 & Yar baş13 \\
şemamok14 & Dirsekli köyü1 \\
şemamok15 & Dirsekli köyü2 \\
şemamok16 & Midyat1 \\
şemamok17 & Midyat-Arabi-Ağustos2 \\
şemamok18 & Midyat33 \\
& C Bostan gülü \\
\hline
\end{tabular}

\section{Result and Discussion}

The highest total Tigger melon fruit yield were obtained as 15 (9740 g / plant), 17 (8437 g/plant), 19 (3234 g / plant), 1 (2807 g / plant). Besides, the lowest Tigger melon yield were obtained as 13 (1164 g / plant), 9 (1172 g / plant), 19 (1172 g / plant) respectively. In addition, the highest fruit weight rose 15 (611 g / fruit), 17 (558 g / fruit), and the lowest Tigger melon yield 8 ( $85 \mathrm{~g} /$ plant), 10 (86 g/ fruit) were obtained respectively (Table 1). The highest Tigger melon fruit lengths were obtained as $15,17(184,152 \mathrm{~mm}$ respectively) and the lowest Tigger melon fruit lenghts 9 and $13(46,51 \mathrm{~mm}$, respectively). There is a significant correlation between fruit weight and fruit length on different melon genotypes (Taha, et al., 2003). The number of fruits on the plant and the average fruit weight are related to the total fruit yield (Feher T. 1993). When we look at the parameters of Table 2 and 3, the highest chlorophyll content was observed in Tigger melon 17 (64.46\%), 19 (55.94\%), and the highest plant main arm length $19(68.42 \mathrm{~cm}), 17(65.98 \mathrm{~cm})$, and accordingly chlorophyll content was found to have a relationship with the main arm length of the plant. It was observed that the main arm length was more developed as the chlorophyll content in the plants increased. Parameters of number of seeds per 18 Tigger fruit (number / fruit), seed weight per fruit (gr / fruit), seed diameter $(\mathrm{mm})$, seed length $(\mathrm{mm})$, are given in Table 3. The maximum number of seeds per fruit was seen on Tigger melon 1,15 and $17(524.25,485.75$ and 426.50, respectively). In the different pumpkin investigations made by Berenji and Papp (2000), it was seen that there is an significant relationship between number of seed per fruit and seed weight per fruit. There was no significant difference between the seed diameter $(\mathrm{mm})$, seed length $(\mathrm{mm})$ of the Tigger 18 melon. Among genotypes, a difference in seed weight ( $\mathrm{g} /$ fruit) per fruit was observed. The seed weight per fruit was seen as Tigger melon 1, 15 and 17 (12.02, 13.54 and $10.45 \mathrm{~g} /$ fruit, respectively). The relationship between the number of seeds per fruit and fruit weight and seed weight per fruit were determined. In addition, as the number of seeds per fruit increased, fruit weight and seed weight per fruit increased. The highest dry matter content was determined in Tigger melon 16, 15 and 1 genotypes (10.15, 9.75 and $9.58 \%$, respectively), while the lowest dry matter content was determined as Tigger melon 3 and 7 genotypes (6.50, 6.73\%, respectively). Highest water soluble dry matter content (WSDM) was determined in Tigger melon 16, 15 and 1 genotypes (8.60, 8.18 and $7.68 \%$ respectively), while lowest soluable dry matter content was determined in Tigger melon 3 and 7 genotypes $(5.18,6.01 \%$, respectively) (Table 2). Accordingly, there is a parallel between the genotypes in both measurements (dry matter and water soluble dry matter). The water-soluble dry matter in different fruits and vegetables consists of fructose, glucose and sucrose and sugars and different acids, respectively (Cemeroglu,1992). 
Table 2. Characteristics of 18 different tigger melon genotypes in brix in fruit, SPAD, dry matter in fruit, total yield, fruit weight, fruit length, fruit width, fruit wall thickness.

\begin{tabular}{|c|c|c|c|c|c|c|c|c|}
\hline Genotype & $\begin{array}{l}\text { Chlorophyll } \\
\text { (SPAD) }\end{array}$ & $\begin{array}{l}\text { Brix in } \\
\text { fruit }(\%)\end{array}$ & $\begin{array}{l}\text { Dry } \\
\text { matter in } \\
\text { fruit }(\%)\end{array}$ & $\begin{array}{l}\text { Total } \\
\text { yield } \\
\text { (g/plant) }\end{array}$ & $\begin{array}{l}\text { Fruit } \\
\text { weight } \\
\text { (g/ } \\
\text { fruit) }\end{array}$ & $\begin{array}{l}\text { Fruit } \\
\text { length } \\
(\mathrm{mm})\end{array}$ & $\begin{array}{l}\text { fruit } \\
\text { width } \\
(\mathrm{mm})\end{array}$ & $\begin{array}{l}\text { fruit wall } \\
\text { thickness } \\
(\mathrm{mm})\end{array}$ \\
\hline semamok1 & $52.69 \mathrm{c}$ & $7.68 \mathrm{c}$ & $9.58 \mathrm{ab}$ & $2807 \mathrm{~d}$ & $123 \mathrm{~d}$ & $62 \mathrm{~d}$ & $64.66 \mathrm{~d}$ & $11.58 \mathrm{~g}$ \\
\hline semamok3 & $34.01 \mathrm{k}$ & 5.181 & $6.50 \mathrm{f}$ & $1567 \mathrm{~g}$ & $102 \mathrm{ef}$ & $56 \mathrm{gh}$ & $54.35 \mathrm{j}$ & $8.72 \mathrm{~g}$ \\
\hline semamok4 & $42.10 \mathrm{~h}$ & $6.79 \mathrm{~d}$ & $8.61 \mathrm{c}$ & $1355 \mathrm{~h}$ & $87 \mathrm{fg}$ & 521 & $49.78 \mathrm{~m}$ & $11.54 \mathrm{c}$ \\
\hline semamok5 & $36.39 \mathrm{j}$ & 6.50 ef & $7.75 \mathrm{~d}$ & $1574 \mathrm{fg}$ & $105 \mathrm{e}$ & $56 \mathrm{gh}$ & $57.79 \mathrm{~h}$ & $9.59 \mathrm{f}$ \\
\hline semamok6 & 31.181 & $6.43 \mathrm{fg}$ & $6.94 \mathrm{ef}$ & $1592 \mathrm{fg}$ & $107 \mathrm{de}$ & $62 \mathrm{~d}$ & 55.771 & $10.19 \mathrm{e}$ \\
\hline semamok7 & $36.41 \mathrm{j}$ & $6.01 \mathrm{~h}$ & $6.73 \mathrm{ef}$ & $1679 \mathrm{ef}$ & $117 \mathrm{de}$ & $56 \mathrm{gh}$ & $57.92 \mathrm{~h}$ & $9.26 \mathrm{f}$ \\
\hline semamok8 & 39.151 & $6.63 \mathrm{~d}-\mathrm{f}$ & $6.79 \mathrm{ef}$ & $1278 \mathrm{~h} 1$ & $85 \mathrm{~g}$ & $58 \mathrm{e}-\mathrm{g}$ & $53.64 \mathrm{j}$ & $8.33 \mathrm{~h}$ \\
\hline semamok9 & $36.40 \mathrm{j}$ & $6.75 \mathrm{de}$ & $7.88 \mathrm{~d}$ & $1172 \mathrm{ij}$ & $78 \mathrm{~g}$ & $46 \mathrm{j}$ & $51.81 \mathrm{k}$ & $9.35 \mathrm{f}$ \\
\hline semamok10 & $43.58 \mathrm{~g}$ & $6.44 \mathrm{fg}$ & $9.30 \mathrm{~b}$ & $1263 \mathrm{~h}-\mathrm{j}$ & $86 \mathrm{fg}$ & $57 \mathrm{f}-\mathrm{h}$ & 55.311 & $8.68 \mathrm{gh}$ \\
\hline semamok11 & $43.68 \mathrm{~g}$ & $6.48 \mathrm{f}$ & $9.45 \mathrm{~b}$ & $1172 \mathrm{ij}$ & $109 \mathrm{de}$ & $64 \mathrm{~d}$ & $47.95 \mathrm{n}$ & 7.441 \\
\hline semamok12 & 38.861 & $6.38 \mathrm{fg}$ & $6.94 \mathrm{ef}$ & $1575 \mathrm{fg}$ & $111 \mathrm{de}$ & $67 \mathrm{c}$ & $67.50 \mathrm{c}$ & $10.56 \mathrm{~d}$ \\
\hline semamok13 & $44.93 \mathrm{f}$ & $6.45 \mathrm{fg}$ & $7.25 \mathrm{de}$ & $1164 \mathrm{j}$ & $80 \mathrm{~g}$ & 511 & $61.75 \mathrm{f}$ & $8.64 \mathrm{gh}$ \\
\hline semamok14 & $46.73 \mathrm{e}$ & $6.03 \mathrm{~h}$ & $7.35 \mathrm{de}$ & $1350 \mathrm{~h}$ & $87 \mathrm{fg}$ & $59 \mathrm{e}$ & 50.871 & $8.64 \mathrm{gh}$ \\
\hline semamok15 & $47.83 \mathrm{~d}$ & $8.18 \mathrm{~b}$ & $9.75 \mathrm{ab}$ & $9740 \mathrm{a}$ & $611 \mathrm{a}$ & $184 \mathrm{a}$ & $73.32 \mathrm{~b}$ & $16.24 \mathrm{a}$ \\
\hline semamok16 & $49.22 \mathrm{c}$ & $8.60 \mathrm{a}$ & $10.15 \mathrm{a}$ & $1738 \mathrm{e}$ & $117 \mathrm{de}$ & $58 \mathrm{ef}$ & $58.10 \mathrm{~h}$ & $11.71 \mathrm{c}$ \\
\hline semamok17 & $64,46 \mathrm{a}$ & $6.20 \mathrm{gh}$ & $9.53 \mathrm{ab}$ & $8437 \mathrm{~b}$ & $558 \mathrm{~b}$ & $152 \mathrm{~b}$ & $63.35 \mathrm{e}$ & $14.48 \mathrm{~b}$ \\
\hline semamok18 & 38.801 & $7.50 \mathrm{c}$ & $7.24 \mathrm{de}$ & $1283 \mathrm{~h} 1$ & $88 \mathrm{fg}$ & $55 \mathrm{~h}$ & $98.20 \mathrm{a}$ & $8.53 \mathrm{gh}$ \\
\hline semamok19 & $55.94 \mathrm{~b}$ & $6.48 \mathrm{f}$ & $7.60 \mathrm{~d}$ & $3234 \mathrm{c}$ & $246 \mathrm{c}$ & $64 \mathrm{~d}$ & $60.10 \mathrm{~g}$ & $10.54 \mathrm{de}$ \\
\hline $\mathrm{LSD}_{0.05}$ & 0.81 & 0.27 & 0.64 & 111.33 & 17.04 & 2.08 & 29.55 & 0.35 \\
\hline
\end{tabular}

18 Tigger melon Number of knuckles on main trunk (number), knuckle length $(\mathrm{cm})$ in main trunk, main trunk diameter $(\mathrm{mm})$, parameters are given in Table 3. Significant differences were found between the lines in terms of main trunk length. The maximum knuckle number on main trunk was seen on 18 Tigger melon 1 (11.82), while minimum knuckle number was seen on 10 and 6 genotypes (6.58 and 6.60, respectively). The diameter of the main trunk was determined as $7.16 \mathrm{~mm}$ in the Tigger melon 5 and $10.32 \mathrm{~mm}$ in the Tigger melon 18 (Table 3). Besides, these parameters were not found in a relationship with total fruit yield. Accordingly, Feizian A. 2004 is consistent with his findings in his study on melon.

Table 3. Characteristics of 18 different tigger melon genotypes in main stem diameter, main stem length, the main number of nodes in the stem, nod in the main stem.

\begin{tabular}{|c|c|c|c|c|c|c|c|c|}
\hline Genotype & $\begin{array}{l}\text { Number of } \\
\text { seeds per fruit } \\
\text { (number/fruit) }\end{array}$ & $\begin{array}{l}\text { Seed } \\
\text { weight } \\
\text { (g/fruit) }\end{array}$ & $\begin{array}{l}\text { Seed } \\
\text { weight } \\
(\mathrm{mm})\end{array}$ & $\begin{array}{l}\text { Seed } \\
\text { length } \\
(\mathrm{mm})\end{array}$ & $\begin{array}{l}\text { Main } \\
\text { number } \\
\text { of nodes } \\
\text { (number) }\end{array}$ & $\begin{array}{l}\text { Nod in } \\
\text { the main } \\
\text { stem } \\
(\mathrm{cm})\end{array}$ & $\begin{array}{l}\text { Main } \\
\text { stem } \\
\text { diameter } \\
(\mathrm{mm})\end{array}$ & $\begin{array}{l}\text { Main } \\
\text { stem } \\
\text { length } \\
(\mathrm{cm})\end{array}$ \\
\hline semamok1 & $524.25 \mathrm{a}$ & $12.02 \mathrm{~b}$ & 3.77 & $8.711-\mathrm{j}$ & $11.82 \mathrm{a}$ & $4.32 \mathrm{a}$ & $8.42 \mathrm{c}$ & $67.91 \mathrm{a}$ \\
\hline semamok3 & $324.75 \mathrm{f}$ & $6.31 \mathrm{f}$ & 3.39 & $8.651-\mathrm{k}$ & $8.83 \mathrm{~b}$ & $3.69 \mathrm{~b}$ & $7.41 \mathrm{~d}$ & 44.27 h1 \\
\hline semamok4 & $186.00 \mathrm{o}$ & $4.42 \mathrm{~h}$ & 3.82 & $9.39 \mathrm{fg}$ & $6.95 \mathrm{e}$ & $1.44 \mathrm{~d}-\mathrm{f}$ & $7.30 \mathrm{~d}$ & $48.33 \mathrm{de}$ \\
\hline semamok5 & 256.751 & $5.47 \mathrm{~g}$ & 3.72 & 8.771 & $11.62 \mathrm{a}$ & $1.53 \mathrm{~d}-\mathrm{f}$ & $7.16 \mathrm{~d}$ & $49.56 \mathrm{~d}$ \\
\hline semamok6 & $217.00 \mathrm{mn}$ & $4.50 \mathrm{~h}$ & 3.48 & $9.53 \mathrm{e}-\mathrm{g}$ & $6.60 \mathrm{e}$ & $1.51 \mathrm{~d}-\mathrm{f}$ & $6.34 \mathrm{e}$ & $40.95 \mathrm{j}$ \\
\hline semamok7 & $315.75 \mathrm{~g}$ & $6.14 \mathrm{f}$ & 3.17 & 7.071 & $11.27 \mathrm{a}$ & $1.24 \mathrm{ef}$ & $8.27 \mathrm{c}$ & 43.871 \\
\hline semamok8 & $213.50 \mathrm{n}$ & $4.37 \mathrm{~h}$ & 3.58 & $8.56 \mathrm{jk}$ & $9.04 \mathrm{~b}$ & $1.55 \mathrm{~d}-\mathrm{f}$ & $7.27 \mathrm{~d}$ & $40.51 \mathrm{j}$ \\
\hline semamok 9 & $281.75 \mathrm{j}$ & $7.14 \mathrm{e}$ & 3.65 & $9.61 \mathrm{e}$ & $11.62 \mathrm{a}$ & $1.38 \mathrm{~d}-\mathrm{f}$ & $7.52 \mathrm{~d}$ & $47.54 \mathrm{ef}$ \\
\hline semamok10 & $285.50 \mathrm{ij}$ & $5.36 \mathrm{~g}$ & 3.31 & $9.18 \mathrm{~h}$ & $6.58 \mathrm{e}$ & $1.14 \mathrm{f}$ & $6.59 \mathrm{e}$ & $49.63 \mathrm{~d}$ \\
\hline semamok11 & $216.75 \mathrm{mn}$ & $4.45 \mathrm{~h}$ & 3.57 & $9.36 \mathrm{gh}$ & $7.49 \mathrm{c}-\mathrm{e}$ & $2.29 \mathrm{c}$ & $7.57 \mathrm{~d}$ & $47.41 \mathrm{ef}$ \\
\hline semamok12 & $369.50 \mathrm{e}$ & $8.62 \mathrm{~d}$ & 3.31 & $8.51 \mathrm{k}$ & $8.22 \mathrm{~b}-\mathrm{d}$ & $1.62 \mathrm{de}$ & $8.35 \mathrm{c}$ & 43.981 \\
\hline semamok13 & $418.00 \mathrm{~d}$ & $8.94 \mathrm{~d}$ & 3.65 & $9.56 \mathrm{ef}$ & $7.32 \mathrm{c}-\mathrm{e}$ & $1.67 \mathrm{~d}$ & $8.62 \mathrm{c}$ & 43.671 \\
\hline semamok14 & 286.501 & $5.28 \mathrm{~g}$ & 3.34 & 8.061 & $8.59 \mathrm{~b}$ & $1.59 \mathrm{de}$ & $9.44 \mathrm{~b}$ & $47.21 \mathrm{e}-\mathrm{g}$ \\
\hline semamok15 & $485.75 \mathrm{~b}$ & $13.54 \mathrm{a}$ & 4.21 & $10.59 \mathrm{~b}$ & $7.45 \mathrm{c}-\mathrm{e}$ & $1.47 \mathrm{~d}-\mathrm{f}$ & $6.40 \mathrm{e}$ & $45.46 \mathrm{~g}-1$ \\
\hline semamok16 & $218.75 \mathrm{~m}$ & $10.40 \mathrm{c}$ & 4.58 & $12.27 \mathrm{a}$ & $8.16 \mathrm{~b}-\mathrm{d}$ & $1.63 \mathrm{de}$ & $9.30 \mathrm{~b}$ & $58.02 \mathrm{c}$ \\
\hline semamok17 & $426.50 \mathrm{c}$ & $10.45 \mathrm{c}$ & 4.25 & $10.24 \mathrm{c}$ & $6.58 \mathrm{e}$ & $1.24 \mathrm{ef}$ & $8.49 \mathrm{c}$ & $65.98 \mathrm{~b}$ \\
\hline semamok18 & $261.50 \mathrm{k}$ & $5.06 \mathrm{~g}$ & 3.26 & $9.85 \mathrm{~d}$ & $7.32 \mathrm{c}-\mathrm{e}$ & $1.65 \mathrm{de}$ & $10.32 \mathrm{a}$ & $45.95 \mathrm{f}-\mathrm{h}$ \\
\hline semamok19 & $294.25 \mathrm{~h}$ & $8.95 \mathrm{~d}$ & 4.50 & $9.53 \mathrm{eg}$ & $7.19 \mathrm{de}$ & $2.37 \mathrm{c}$ & $7.46 \mathrm{~d}$ & $68.42 \mathrm{a}$ \\
\hline $\mathrm{LSD}_{0.05}$ & 4.19 & 0.48 & Öd & 0.18 & 4.27 & 1.71 & 1.70 & 1.81 \\
\hline
\end{tabular}


group contains $17,8,4,5,10,9,7,3,12,13,11,6$. And number 2 genotypes are the most similar genotypes. And it was found that number 2 genotypes are the most similar genotypes. It was determined that the most similar genotypes are 4, 8 genotype pairs, while the most different genotype pairs were 1, 17, 2, 5 and 12 . The most significant of all genotypes evaluated are $1,17,2$, while the least significant ones are 13,8 . In addition, the most remote genotype was determined as 1 (Figure 2).
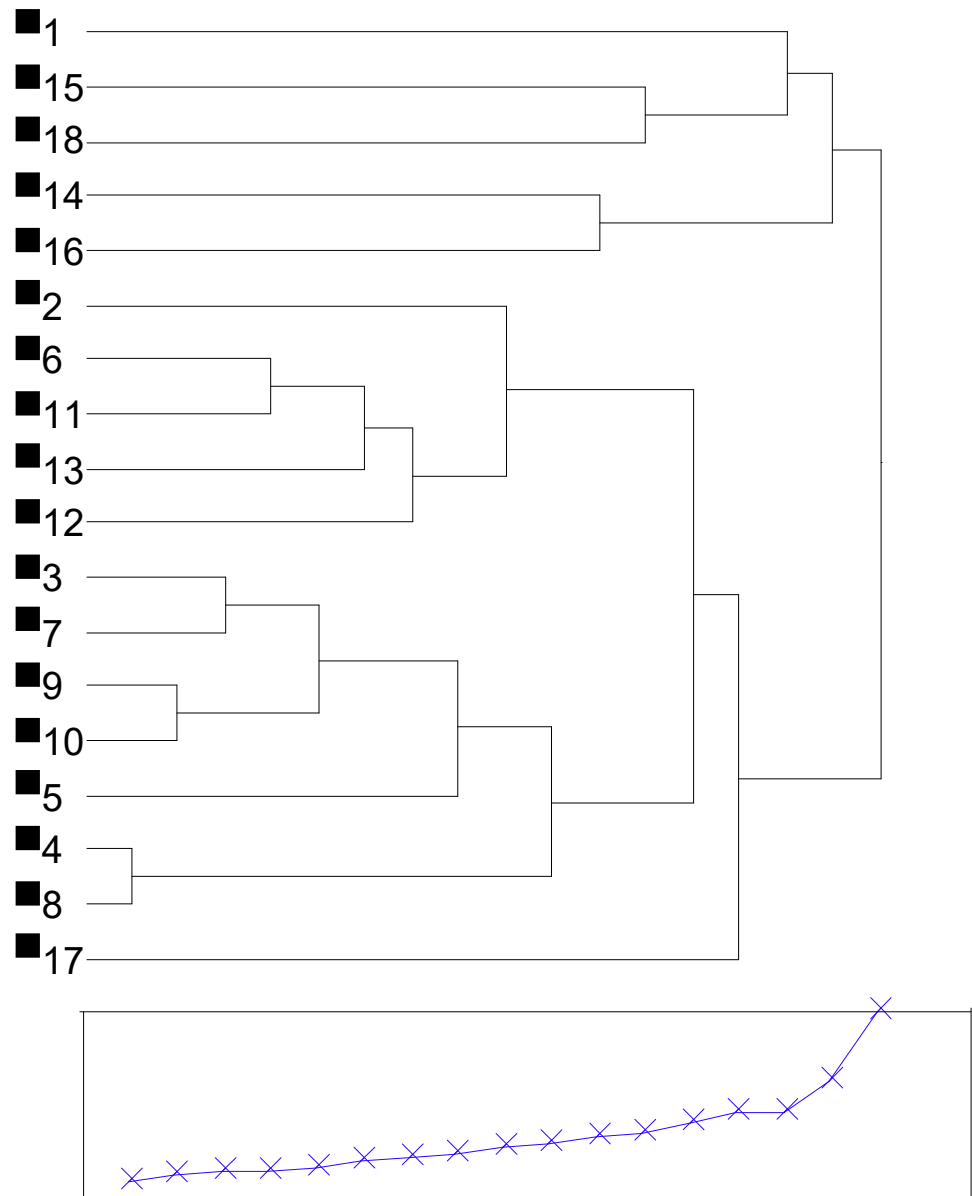

Figure 2. Cluster analysis of some morphological characteristics of 18 different Tigger melon genotypes of Idil / Sirnak region.

\section{Conclusion}

Conservation and preservation of gene resources in plants, their utilization in breeding studies, determining and keeping under the records the differences between genotypes by examining the physiological, morphological and pomological characteristics will be useful to our study. In addition, in the following stages, it is aimed to make use of aroma analysis in the fruit of 18 tigger melon to use the prominent genotypes of the best genotypes in our breeding studies.

\section{References}

Anonymous. (2010). FAOSTAT. Statistic Database. http://faostat.fao.org/

Anonymous. (2013). http://ecocrop.fao.org/ecocrop/srv/en/home.

Berenj1, J., Papp, D. (2000). Interrelations Among Fruit and Seed Characteristics of Oil Pumpkin, $7^{\text {th }}$ EUCARPIA Meeting on Cucurbit Genetics and Breeding, ISHS Acta Horticulturae, 510.

Cemeroglu, B. (1992). Basic Analysis Methods in Fruit and Vegetable Processing Industry. Biltav Publications, Ankara.

Duke, J. A., and Ayensu, E. S. (1985). Medicinal plants of China. Reference Publications, Algonac, MI.

Feher, T. (1993). Watermelon: Genetic improvement vegetable crops. Pergmon press. Oxford. New York.

Feizian, A. (2004). Collection of Melons Genotypes of north and center of Iran and evaluation of diversity with RAPID. Msc. Thesis. Modares Uniesity. Iran. 100 p.

Jeffrey, C. (2001). Cucurbitacae. In: Hanelt P. and Institute of Plant Genetics and Crop Plant Research (eds.), Mansfeld's Encyclopedia of Agricultural and Horticultural Crops. Springer, New York, NY, USA. 
Karaagac, O., and Baklaya, A. (2009). Bafra Red Pepper Populations (Capsicum annuum L. var. Conoides (Mill.) Irish) Identification and Evaluation of Existing Variation. Anadolu Journal of Agricultural Sciences. 25(1):10-20.

. Lorenzı, H., Bacher, L., Lacerda, M., Sartorı, S. (2006). Frutas brasileiras e exóticas cultivadas: de consumo in natura. Nova Odessa: Instituto Plantarum de Estudos da Flora, 674p.

Pitrat, M., Chauvet, M., Foury, C. (1999). Diversity, history and production of cultivated cucurbits. Proc. 1 st Int. Symp. on Cucurbits. (Eds. K. Abak \& S. Büyükalaca.) Acta. Hort. 492:21-28.

Sensoy, S., Buyukalaca, S., Abak, K. (2007). Evaluation of genetic diversity in Turkish melons (Cucumis melo L.) based on phenotypic characters and RAPD markers. Genet. Resour. Crop. Evol. 54:1351-1365.

Sensoy, S., Turkmen O., Ceknas E. (2008). Comparison of some local melon genotypes selected from Lake Van Basin with some commercial melon cultivars for some yield and quality related traits observed in field and high tunnel conditions. African Journal of Biotechnology. 7(22):4105-10.

Soltani, F., Akashi, Y., Kashi, A., Zamani, Z., Mostofi, Y., Kato, Y. (2010). Characterization of Iranian melon landraces of Cucumis melo L. groups flexuosus and dudaim by analysis of morphological characters and random amplified polymorphic DNA. Breeding Science, 60 (1):34-45.

Tanaka, T., and Nakao, S. (1976). Tanaka's cyclopedia of edible plants of the world.

Taha, M., Omara, K., and Jack, A. (2003). Correlation among growth yield and quality characters in cucumis mlo. Cucurbit Genetics Cooperative Report.26:9-11.

Tindall, H. D. (1983). Vegetables in the tropics. pp.533 pp. ref.many. 